\title{
Smoke-Free Adolescents. Effectiveness of an educational intervention. Controlled, before and after study
}

\author{
Pablo E. Gulayin, M.D. ${ }^{a, b}$, Vilma Irazola, M.D. ${ }^{a}$, Adolfo Rubinstein, M.D. ${ }^{c}$, \\ Rodrigo Bruno, M.D. ${ }^{d}$, André Rossi Díaz, M.D. e, Miguel Gulayin, M.D.e, \\ María I. Urrutia, Engineerf and Ariel Bardach, M.D. ${ }^{a}$
}

\begin{abstract}
Smoking is considered the main cause of preventable death worldwide. Most smokers start using tobacco at an early age, especially during adolescence. The objective of this study was toidentify the determinants of adolescentuse of tobacco and assess the impact of an educational intervention on the prevalence of smoking.

Methods. Controlled, before and after study conducted between 2010 and 2012 at two secondary schools in the city of La Plata. A baseline survey was administered at both schools followed by two subsequent measurements; an educational intervention aimed at youth aged 12 and 13 years was implemented in one of the schools. Multiple regression models were used to identify the outcome measures associated with smoking and assess the impact of the intervention.
\end{abstract}

a. Instituto de Efectividad Clínica y Sanitaria, IECS, Buenos Aires, Argentina.

b. Public Health, School of Medical Sciences, Universidad Nacional de La Plata.

c. National Ministry of Health of Argentina.

d. Sanatorio Belgrano, Mar del Plata.

e. Hospital Rodolfo Rossi, La Plata.

f. Centro Superior para el Procesamiento de la Información, CeSPI, Universidad Nacional de La Plata.

E-mail address:

Pablo Gulayin, M.D.: pgulayin@iecs.org.ar

Funding:

None

Conflict of interest: None.

Received: 7-3-2017 Accepted: 12-7-2017
Results. A total of 1911 surveys were included (school A: 617; school B: 1294). The outcome measures associated with adolescent smoking were having a sibling who smokes (odds ratio [OR]: 2.55), a mother who smokes (OR: 2.32), age (OR: 1.92), and female sex (OR: 1.75). The OR adjusted for these determinants to be a current smoker at the intervention school versus the control school was 0.54 (95\% confidence interval [CI]: 0.35-0.83) in the first year of follow-up and 0.98 (95\% CI: $0.60-1.61)$ in the second year.

Conclusions. Having a mother or a sibling who smokes, age, and female sex were strongly correlated to cigarette smoking. The educational intervention had a positive effect in the first year of follow-up, which was not maintained over time.

Key words: smoking, adolescents, education, prevention.

http:/ / dx.doi.org/10.5546/ aap.2018.eng.e392

To cite: Gulayin PE, Irazola V, Rubinstein A, et al. Smoke-Free Adolescents. Effectiveness of an educational intervention. Controlled, before and after study. Arch Argent Pediatr 2018;116(3):e392-e400.

\section{INTRODUCTION}

Tobacco use causes 5.1 million deaths every year worldwide ${ }^{1}$ and is considered the leading cause of preventable death and one of the most serious public health problems. ${ }^{2,3}$
Most of these deaths take place in developing countries, where tobacco use has increased, especially among the more vulnerable groups: ${ }^{4}$ youth and women. 5,6

The damaging effects of tobacco use on health start since initiation during adolescence, and it has been observed that $88 \%$ of adult smokers started smoking before 18 years old. ${ }^{7,8}$ The most recent Worldwide Survey on School Health in Argentina, ${ }^{9}$ administered to secondary school students, showed that a high rate of youth had tried tobacco, that they were highly exposed to secondhand smoke and knew little of the harmful effects of tobacco, and that there was a high tendency to start smoking among non-smokers.

Several articles in National Law No. 26687 and the MPOWER Measures of the World Health Organization $(\mathrm{WHO})^{2}$ for the regulation of the advertising, promotion, and use of tobacco products are aimed at smoking prevention among youth. Although positive advances have been reported in implementing the law, ${ }^{10-13}$ there is a significant gap in relation to studies and field work focused on smoking prevention among youth. Data on the effectiveness of interventions aimed at the primary prevention of smoking at an early age show, in general, positive results, in spite of the heterogeneity of the methodologies used and the controversies regarding the maintenance of the changes brought about. ${ }^{14-19}$ Using simulation models, it has been estimated how the age restriction at smoking initiation among youth might help to reduce the proportion of smoking 
among adults. ${ }^{20}$ As far as we know, no health interventions on this topic in the education sector of Argentina have been scientifically evaluated.

The objective of the Smoke-Free Adolescents (SMA) study was to identify the determinants of adolescent use of tobacco and assess the impact of an educational intervention on the prevalence of smoking.

\section{POPULATION AND METHODS Design}

The SMA is a controlled, before and after study that used a survey administered for three years in a row to the students of two secondary schools in the city of La Plata. This type of quasiexperimental design is especially useful to assess the effectiveness of educational interventions. ${ }^{21}$ Measurements from the control group are strongly helpful to know the baseline differences between groups and assess secular changes, which makes it possible to determine the external outcome measures that influence the desired effect for reasons other than the intervention.

\section{Population and data collection}

Schools were selected by convenience; it is worth noting that these national public schools were the largest ones in town. The number of enrolled students accounted for approximately $13.5 \%$ of all secondary school students enrolled in the public sector of the center of La Plata. ${ }^{22}$ Both participating secondary schools were public, coeducational institutions that admitted students by lot, so the school population was heterogeneous in terms of social and cultural characteristics. The school where the intervention was implemented was referred to as school $\mathrm{A}$ (SA) and the control school, as school B (SB).

For analysis and follow-up purposes, students were classified based on their school year in 2010: first year students (G1), second and third year students (G2), and fourth and fifth year students (G3). The same school year groups from SB made up the control group. The final analysis included only those school year groups that completed the follow-up.

In September 2010, a baseline survey (Annex 1) was administered to the students of participating schools. The survey was re-administered in November 2011 and November 2012. The instrument was a structured, anonymous, voluntary, and self-administered survey. The questionnaire structure was based on the outcome measures described in studies on smoking among student populations from Argentina and IberoAmerica. ${ }^{23-28}$ Current adolescent smokers were defined as students who reported smoking on a daily or almost daily basis.

The Higher Institute of Information Processing (Centro Superior para el Procesamiento de la Información, CeSPI), the computing center of Universidad Nacional de La Plata, helped to load data into the study database.

\section{The educational intervention}

The educational intervention was aimed at preventing smoking initiation and was exclusively implemented in G2 of SA following the baseline survey in 2010 (direct intervention). G1 and G3 of SA were considered indirect intervention groups taking into account the possibility that the students at this school could have siblings or teachers in common or could be indirectly exposed to any of the components of the direct intervention received by G2 (e.g., final exhibition of posters in the school corridors).

The intervention's thematic units (Annex 2) included the main topics of the Manual for Smoke-Free Schools ${ }^{29}$ and were developed through the following three activities: (1) two debate-talks on the damages caused by smoking, a public health approach to the problem, and the current Argentine laws on this issue; (2) small group workshops where students were asked to design posters based on the thematic units; and (3) exhibition of the final posters made by the students at school. Each talk lasted 40 minutes, and the last 10 minutes were allocated to questions. The team responsible for implementing the intervention included research physicians, who conducted the talks, and the schools' Biology teachers, who helped with the coordination. Both talks were interactive and included images related to the thematic unit and an invitation for students to discuss and reflect on the topic. Then teachers discussed the thematic units analyzed at the meetings with physicians in each classroom for at least 4 months. Teachers coordinated poster design in small groups of students in a final workshop. Ten workshops were conducted, one for each school year in the intervention group of SA, with a maximum of 30 students per workshop. Workshops lasted two teaching hours each and were conducted over three months once each group had worked on the topics discussed in the debate-talks for at least four months. The last step of the intervention consisted in the display of all posters designed by G2 of SA in the school 
corridors. This way, posters were shown to the entire school community and remained in place until the end of the last workshop.

\section{Statistical analysis}

To compare the population's baseline characteristics, Fisher's exact test was used for categorical outcome measures and the $t$ test, for continuous outcome measures. A multivariate logistic regression model was developed for outcome measures associated with cigarette smoking in this population. The multiple models were compared using tests for nested models (likelihood ratio tests) and the Akaike information criterion/Bayesian information criterion (AIC/ BIC). ${ }^{30,31}$ The calibration of the final model was assessed using the Hosmer-Lemeshow test and the c-statistic was estimated to build a receiver operating characteristic (ROC) curve. At each assessed cut-off point, the proportions of the primary endpoint were compared using Fisher's exact test so as to establish the statistical significance. In turn, the odds ratio (OR) was estimated for the "current smoker" outcome in SA versus SB, adjusted for the factors associated with smoking included in the initially developed model. For all analyses, a two-tailed p value $<0.05$ was considered a statistically significant difference. The statistical software package used was Stata 13.0.

\section{RESULTS \\ Baseline measurement}

Based on the total number of enrolled students at the time of the survey, the rate of overall response was $88 \%$ in SA and $77.5 \%$ in SB; Table 1 shows the absolute values. A total of 1911 surveys (617 from SA and 1294 from SB) administered to first through fifth year students were included.

Table 2 describes the characteristics of the surveyed population. It is worth noting the higher proportion of girls in SA. No significant differences were observed in the overall prevalence of smoking between both schools before the intervention (SA: $7.8 \%$ versus SB:

TABLE 1. Sample distribution by school, group, and survey year

\begin{tabular}{|c|c|c|c|c|}
\hline \multirow{4}{*}{ 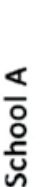 } & & $\frac{\text { Surveyed }}{\text { Enrolled }}$ & Excluded* & Group distribution \\
\hline & 2010 & $617 / 675$ & 22 & G1: 138 / G2:256 / G3: 201 \\
\hline & 2011 & $558 / 642$ & 0 & G1: 148 / G2:240 / G3: 170 \\
\hline & 2012 & $341 / 405$ & 0 & G1: 132 / G2:209 / G3: ** \\
\hline$\infty$ & 2010 & $1294 / 1443$ & 255 & G1: 276 / G2:431 / G3: 332 \\
\hline 응 & 2011 & $946 / 1408$ & 92 & G1: 267 / G2:306 / G3: 281 \\
\hline$u$ & 2012 & $615 / 833$ & 0 & G1: $260 /$ G2:355 / G3: ** \\
\hline
\end{tabular}

* Surveys excluded because they corresponded to school years that did not complete the follow-up.

** G3 was not assessed in 2012 because half of students had graduated from school.

TABLE 2. Baseline characteristics of students from participating schools before the intervention

\begin{tabular}{|c|c|c|c|}
\hline & $\begin{array}{c}\text { School A (intervention) } \\
\qquad \mathrm{N}=617\end{array}$ & $\begin{array}{c}\text { School B (control) } \\
\mathrm{N}=1294\end{array}$ & $p^{\Psi}$ \\
\hline Average age (SD) & $14.2( \pm 1.18)$ & $14.2( \pm 1.20)$ & 0.793 \\
\hline Female sex, $\mathrm{n}(\%)$ & $341 / 613(55.6)$ & $522 / 1284(40.7)$ & 0.01 \\
\hline Overall prevalence of smoking, n (\%) & $48 / 611(7.8)$ & $91 / 1277(7.1)$ & 0.572 \\
\hline \multicolumn{4}{|l|}{ Prevalence of smoking per school year: } \\
\hline First year, $\mathrm{n}(\%)$ & $3 / 134(2.2)$ & $2 / 273(0.7)$ & 0.339 \\
\hline Second year, n (\%) & $4 / 119(3.4)$ & $7 / 282(2.5)$ & 0.738 \\
\hline Third year, $\mathrm{n}(\%)$ & $12 / 137(8.8)$ & $16 / 278(5.8)$ & 0.297 \\
\hline Fourth year, n (\%) & $14 / 125(11.2)$ & $32 / 226(14.2)$ & 0.510 \\
\hline Fifth year, $\mathrm{n}(\%)$ & $15 / 96(15.6)$ & $34 / 218(15.6)$ & 1.000 \\
\hline Former smoker, $\mathrm{n}(\%)$ & $23 / 611(3.7)$ & $30 / 1277(2.3)$ & 0.100 \\
\hline Experimental smoker, $\mathrm{n}(\%)$ & $127 / 611(20.8)$ & $276 / 1277(21.6)$ & 0.719 \\
\hline Friends who smoke, $\mathrm{n}(\%)$ & $456 / 607(75.1)$ & $980 / 1269(77.2)$ & 0.322 \\
\hline Living with at least 1 smoker, $\mathrm{n}(\%)$ & $318 / 617(51.5)$ & $637 / 1294(49.2)$ & 0.353 \\
\hline Father who smokes, n (\%) & $172 / 617(27.9)$ & $336 / 1294(26)$ & 0.376 \\
\hline Mother who smokes, n (\%) & $164 / 617(26.6)$ & $329 / 1294(25.4)$ & 0.615 \\
\hline Siblings who smoke, $\mathrm{n}(\%)$ & $65 / 617(10.5)$ & $130 / 1294(10)$ & 0.747 \\
\hline
\end{tabular}

¥ Two-tailed $\mathrm{p}$ value for the $\mathrm{t}$ test in the case of the continuous outcome measure "age” and two-tailed Fisher's exact test for the remaining outcome measures.

SD: standard deviation. 
$7.0 \%, \mathrm{p}=0.572)$. Among the 139 smokers in 2010, $48.6 \%$ corresponded to daily smokers. Among smokers, $91.5 \%$ had started before 16 years old. Participants' average age at initiation was 13.40 \pm 1.67 years. Also, the baseline survey did not find significant differences in the prevalence of smoking per school year, and it clearly increased among older students.

\section{Predictors of smoking among adolescents}

The outcome measures included in the final multiple model were having a sibling who smokes, having a mother who smokes, age, and female sex. Table 3 shows the ORs and their corresponding $95 \%$ confidence intervals. The final model was assessed using the Hosmer-Lemeshow test $(\mathrm{p}=0.133)$ and an area under the ROC curve of 0.83 .

\section{Population follow-up and the impact of the intervention}

The overall response rate in G2 of SA, who received the intervention, was $89.2 \%$ and $85.4 \%$ before and after the intervention. The same group of SB showed a baseline response rate of $89.9 \%$ and $83.2 \%$ during follow-up.
Table 4 shows the prevalence of students who smoked per group, sex, and school in each survey (the baseline survey from 2010 and the two surveys following the educational intervention, in 2011 and 2012). When comparing the overall proportions, a significant difference was observed only in the prevalence of smoking in the first year following the intervention (SA: $4.6 \%$ versus SB: 11.4; $\mathrm{p}=0.005)$, which disappeared in the second year of follow-up. The stratified analysis by sex showed a statistically significant difference among girls and only in the first year of the intervention (SA: $4.7 \%$ versus SB: $11.4 ; \mathrm{p}=0.048$ ).

Figure 1 shows the detailed ORs for current smokers in the direct intervention group of SA compared to the corresponding control group of SB by year of follow-up. These ORs were adjusted for the most important determinants of smoking observed in this population (sex, age, mother who smokes, and sibling who smokes).

\section{DISCUSSION}

In relation to the baseline characteristics of both schools, it is worth noting as a big difference that SB was larger and included twice as much classrooms than SA and that SA had a higher

TABLE 3. Outcome measures associated with smoking in the baseline population included in the final multiple model

\begin{tabular}{lccc}
\hline & Odds ratio & 95\% confidence interval & p \\
\hline Sibling who smokes & 2.55 & $(1.61-4.04)$ & $<0.001$ \\
Mother who smokes & 2.32 & $(1.58-3.40)$ & $<0.001$ \\
Age & 1.92 & $(1.67-2.21)$ & $<0.001$ \\
Female sex & 1.75 & $(1.20-2.54)$ & 0.003 \\
\hline
\end{tabular}

TABLE 4. Prevalence of current smoking by age groupand sex in relation to the year of follow-up

\begin{tabular}{|c|c|c|c|c|c|c|c|}
\hline & \multicolumn{3}{|c|}{ School A (intervention) $\%$} & \multicolumn{3}{|c|}{ School B (control) \% } & \multirow[t]{2}{*}{$p^{¥}$} \\
\hline & Girls & Boys & Overall & Girls & Boys & Overall & \\
\hline \multicolumn{8}{|c|}{ Group 1* (first year, 12 years old at baseline) } \\
\hline Year 2010 & 1.3 & 1.6 & 1.5 & 2.3 & 0 & 0.7 & 0.604 \\
\hline Year 2011 & 1.3 & 0 & 0.7 & 3.4 & 3.4 & 3.4 & 0.104 \\
\hline Year 2012 & 3.6 & 6.9 & 5.3 & 8.3 & 7.4 & 7.7 & 0.527 \\
\hline \multicolumn{8}{|c|}{ Group $2^{* *}$ (second-third year, $13-14$ years old at baseline) } \\
\hline Year 2010 & 3.9 & 8.8 & 6.2 & 3.7 & 2.3 & 3.0 & 0.050 \\
\hline Year 2011 & 4.7 & 4.6 & 4.6 & 11.4 & 11.1 & 11.4 & 0.005 \\
\hline Year 2012 & 8.0 & 13.8 & 11.0 & 12.2 & 8.2 & 10.1 & 0.777 \\
\hline \multicolumn{8}{|c|}{ Group $3^{* * *}$ (fourth-fifth year, 15-16 years old at baseline) } \\
\hline Year 2010 & 15.6 & 9.0 & 12.9 & 17.0 & 13.0 & 15.1 & 0.525 \\
\hline Year 2011 & 12.5 & 14.1 & 12.9 & 20.8 & 15.3 & 18.2 & 0.187 \\
\hline
\end{tabular}

¥ Two-tailed p value for Fisher's exact test for the overall proportions. * Total N of group 1, school A: 138 (2010), 148 (2011), and 132 (2012); school B: 276 (2010), 267 (2011), and 260 (2012). ** Total N of group 2, school A: 256 (2010), 240 (2011), and 209 (2012); school B: 431 (2010), 306 (2011), and 355 (2012). ${ }^{* * *}$ Total N of group 3, school A: 201 (2010), and 170 (2011); school B: 332 (2010), and 281 (2011). 
rate of girls. The latter is related to the fact that before being coeducational institutions, SA had historically been a girls' school and SB, a boys' school. No qualitative differences were observed in the other studied outcome measures in terms of tobacco epidemiology in both schools at baseline. In the studied population, having a mother or a sibling who smokes, age, and female sex were strongly correlated to cigarette smoking. As described in national surveys, the following was observed: there is a higher rate of cigarette smoking among girls, most students started smoking between 13 and 15 years old, and half of students reported exposure to second-hand smoke at home..$^{32}$

In relation to the impact on the prevalence of smoking in the direct intervention group, the natural increase of the prevalence of smoking shown in the first survey lessened following the intervention, although this effect completely disappeared by the time the third survey was conducted, 27 months later. This means that, whereas a statistically significant difference of $6.8 \%$ was observed in the prevalence of smoking in the first follow-up, such gap faded in the second follow-up. The lower rate of adolescent use of tobacco found in the first survey was reflected in an OR for smoking in SA versus SB of $0.54(0.35-0.83)$. It is worth noting that this tendency was statistically significant among girls. Although a potential contamination effect had been foreseen, no significant differences were observed between the indirect intervention groups and the control groups.

This study poses the following limitations: first of all, the sample exclusively represents data of two downtown schools from the city of
La Plata, so the results cannot be generalized; second, as in the national surveys on tobacco use among youth in Argentina, these results are only applicable to students who were present on the day of the survey; and, finally, all data were selfreported, so youth behaviors might have been under- or over-reported. However, the reliability of surveys on smoking habits among youth has demonstrated to be among the highest ones in relation to adolescent risk behaviors. ${ }^{33}$

The reasons why the primary effect (significant reduction in the prevalence of smoking at the end of follow-up) was not maintained may be: (1) Insufficient intervention duration, given that it was implemented only following the baseline survey in the first year of the study. This may suggest that primary prevention interventions should be continuous or, at least, that the implementation of "booster doses" should be considered, as in the case of immunizations at a population level. (2) A late intervention: students who received the intervention in 2010 were 12 13 years old and 14-15 years old at the end of follow-up. (3) The high prevalence of smoking at home, which is one of the determinants for smoking initiation among youth.

From the public health perspective, the challenge of adolescent smoking is to continue developing and strengthening a favorable environment for smoking cessation among youth that would also help to reduce initiation, and to include innovative strategies that can be adapted to the reality of youth. In relation to the format and components of the educational intervention, the team proposes the following improvements for future assessment: (A) to conduct interventions among youth at a younger

FIGURE 1. Odds ratio for smoking by year (school A or intervention versus school B or control)*

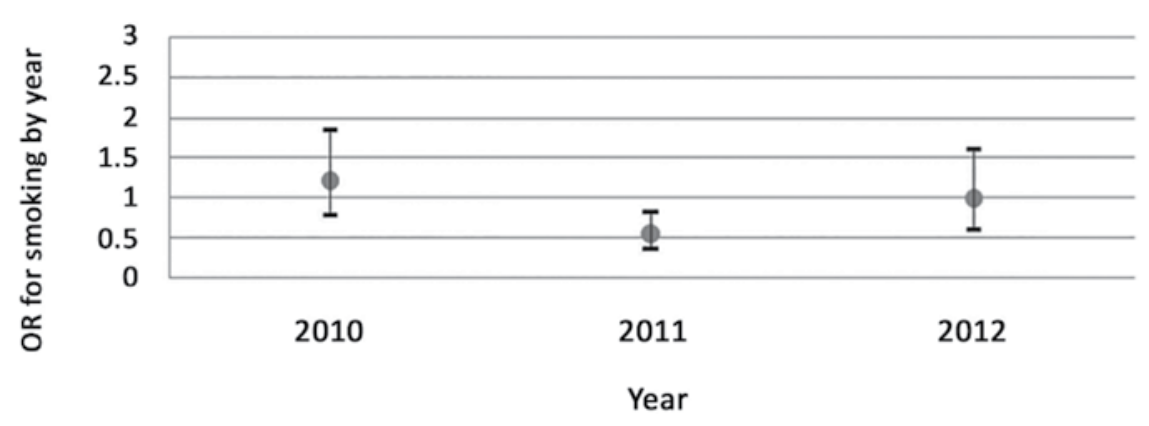

\footnotetext{
* The dots indicate the estimated OR for SA versus SB adjusted for sex, age, mother who smokes, and sibling who smokes; the accompanying pins indicate the corresponding 95\% CI. 2010: 1.2 (0.79-1.84); 2011: 0.54 (0.35-0.83); 2012: 0.98 (0.60-1.61). OR: odds ratio.
} 
age, (B) to implement shorter interventions that could be repeated throughout the school year (e.g., strengthening or creating a space for "health education" at school); (C) to considering the assessment of sex-specific interventions, given that women start smoking at this age but, in turn, they are the ones who better responded to the intervention; and (D) to include new technologies that are widely used by adolescents, such as text messages, social media, etc. To our knowledge, this is the first study that has assessed the effect of an educational intervention on primary smoking prevention implemented in secondary schools of Argentina.

The SMA educational intervention to control tobacco use resulted in a significant reduction in the prevalence of smoking in the first year of follow-up, which was not maintained in the second year.

\section{CONCLUSIONS}

Having a mother or a sibling who smokes, age, and female sex were strongly correlated to cigarette smoking. A deeper understanding of the results of this type of interventions, the epidemiology of smoking among youth, and their behavior in relation to tobacco are essential tools to develop more effective and longer-lasting educational interventions. The development of healthy lifestyle behaviors at an early age should be one of the main targets of research and public health investments.

\section{REFERENCES}

1. Global health risks: mortality and burden of disease attributable to selected major risks. Geneva: World Health Organization; 2009. [Accessed on: November 27th, 2017]. Available at: http://apps.who.int/iris/ handle/10665/44203.

2. Informe OMS sobre la epidemia mundial de tabaquismo, 2008. Plan de medidas MPOWER. Ginebra: Organización Mundial de la Salud, 2008. [Accessed on: November 27th, 2017]. Available at: http:/ / www.who.int/tobacco/ mpower/2008/es/.

3. Rubinstein A, Colantonio L, Bardach A, et al. Estimación de la carga de las enfermedades cardiovasculares atribuible a factores de riesgo modificables en Argentina. Rev Panam Salud Pública 2010;27(4):237-45.

4. Bardach A, Perdomo HA, Gándara RA, et al. Niveles de ingreso y prevalencia de tabaquismo en América Latina: una revisión sistemática y metaanálisis. Rev Panam Salud Pública 2016;40(4):263-71.

5. Lee S, Ling PM, Glantz SA. The vector of the tobacco epidemic: tobacco industry practices in low- and middleincome countries. Cancer Causes Control 2012;23(Suppl 1):117-29.

6. Lim SS, Vos T, Flaxman AD, et al. A comparative risk assessment of burden of disease and injury attributable to 67 risk factors and risk factor clusters in 21 regions, 1990-
2010: a systematic analysis for the Global Burden of Disease Study 2010. Lancet 2012; 380(9859):2224-60.

7. Preventing Tobacco Use Among Youth and Young Adults: A Report of the Surgeon General. Atlanta, GA. United States. Department of Health and Human Services. 2012. [Accessed on: November 27th, 2017]. Available at: https: / / www.surgeongeneral.gov/library/reports/preventingyouth-tobacco-use/index.html\#Additional\%20Resources.

8. Colombo E, Ghignone S, Castaño C, et al. Tabaquismo. Arch Argent Pediatr 2005; 103(5):450-75.

9. Encuesta Mundial de Salud Escolar. Buenos Aires: Ministerio de Salud; 2013. [Accessed on: November 27th, 2017]. Availableat:http: / / www.msal.gob.ar/ent/images/ stories / vigilancia / pdf / 2014-05_informe-EMSE-2013resumen-ejecutivo.pdf.

10. Ministerio de Salud. Monitoreo del cumplimiento de la legislación sobre ambientes libres dehumoen 15 ciudades de Argentina. Boletín de Vigilancia Enfermedades No Transmisibles y Factores de Riesgo 2011; (4):25-34.

11. Ministerio de Salud. Reducción de los ingresos hospitalarios por síndromes coronarios agudos luego de la implementación exitosa de la legislación 100\% libre de humo. Boletin de Vigilancia de Enfermedades No Transmisibles y Factores de Riesgo 2012; (1):75-80.

12. Schoj V, Alderete M, Ruiz E, et al. The impact of a $100 \%$ smoke-free law on the health of hospitality workers from the city of Neuquen, Argentina. Tob Control 2010; 19(2): 134-7.

13. AlcarazA, CaporaleJ, Bardach A, et al. Carga de enfermedad atribuible al uso de tabaco en Argentina y potencial impacto del aumento de precio a través de impuetos. Rev Panam Salud Pública 2016; 40(4):204-12.

14. FernándezS, Nebot M, Jané M. Evaluación de la efectividad de los programas escolares de prevención del consumo de tabaco, alcohol y cannabis: ¿Qué nos dicen los metaanálisis? Rev Esp Salud Pública 2002; 76(3):175-87.

15. Laniado-Laborín R, Molgaard CA, Elder JP. Efectividad de un Programa de Prevención de Tabaquismo en Escolares Mexicanos. Salud Pública Méx 1993; 35(4):403-8.

16. López González ML, Comas Fuentes A, Herrero Puente $\mathrm{P}$, et al. Intervención Educativa Escolar para prevenir el Tabaquismo: Evaluación del Proceso. Rev Esp Salud Pública 1998; 72(4):303-18.

17. Lovato CY, Pullman AW, Halpin P, et al. The influence of school policies on smoking prevalence among students in grades 5-9, Canada, 2004-2005. Prev Chronic Dis 2010; 7(6):A129.

18. Patnode CD, O'Connor E, Whitlock EP, et al. Primary Care-Relevant Interventions for Tobacco Use Prevention and Cessation in Children and Adolescents: A Systematic Evidence Review for the U.S. Preventive Services Task Force. Ann Intern Med 2013; 158(4):253-60.

19. Villalbí JR, Aubá J, García-González A. Evaluación de un Proyecto de Prevención Primaria del Tabaquismo: El proyecto piloto PASE de Barcelona. Rev San Hig Públ 1992; 66(2):143-8.

20. Borracci RA, Mulassi AH. El consumo de tabaco en la adolescencia puede predecir al tabaquismo durante la adultez: investigación basada en modelos de simulación. Arch Argent Pediatr 2015; 113(2):106-12.

21. Manterola C, Otzen O. Estudios Experimentales $2^{a}$ Parte: Estudios Cuasi-Experimentales. Int J Morphol 2015; 33(1):382-7.

22. Dirección de Cultura y Educación. Estadística y evaluación de programas especiales. La Plata: Municipalidad de La Plata; 2017. [Accessedon: October 4th, 2017]. Available at: http: / / www.estadistica.laplata.gov.ar/paginas / matricula.htm\#1. 
23. Linetzky B, Feehan DM, Virgolini M. Encuesta Mundial de Tabaquismo en Adolescentes en Argentina: resultados de 2007 y comparación con encuestas previas, Argentina, mayo 2009.- Buenos Aires: Ministerio de Salud, 2009. [Accessed on: March 21st, 2016]. Available at: http: / / www.msal.gov. $\mathrm{ar} /$ images/stories/bes/graficos/0000000005cnt-encuestatabaquismo-adolescentes_2007.pdf.

24. Suárez Lugo N, Campos Pupo E. Prevalencia y percepción del riesgo del tabaquismo en el área de salud del policlínico "Dr. Jorge Ruiz Ramírez". Rev Cubana Salud Pública 2010; 36(2):125-31.

25. Azevedo A, Machado AP, Barros H. Consumo de Tabaco entre Estudiantes de Secundaria Portugueses. Boletín de la Organización Mundial de la Salud 1999; (1):87-92.

26. Bolzán A, Peleteiro R. Tabaquismo durante la adolescencia temprana. Estudio en escolares argentinos. J Pediatr (Rio J) 2003; 79(5):461-6.

27. Marrón Tundidor R, Pérez Trullén A, Clemente Jiméndez ML, et al. Factores de Inicio del Consumo de Tabaco en Adolescentes. Prevención del Tabaquismo 2003; 5(4):219-34.
28. Pitarque R, Bolzán A, Gatella ME, et al. Tabaquismo en adolescentes escolarizados de la ciudad de Olavarría, Buenos Aires. Prevalencia y factoresasociados. Arch Argent Pediatr 2007; 105(2):115-21.

29. Programa Nacional del Control de Tabaco. Manual de Escuelas Libres de Humo. Buenos Aires: Ministerio de Salud; 2011. [Accessed on: April 11th, 2017]. Available at: http:/ / www.msal.gob.ar/tabaco/images/stories/infoequipos-de-salud/pdf/manual-escuelas-tabaco.pdf.

30. Schwarz G. Estimating the dimension of a model. Ann Stat 1978; 6(2):461-4.

31. Hamparsum B. Model Selection and Akike's information criterios (AIC): The general theory and its analytical extensions. Psychometrika 1987; 52(3):345-70.

32. Konfino J, Ferrante D, Goldberg L, et al. Tobacco use among youths--Argentina, 2007 and 2012. MMWR Morb Mortal Wkly Rep 2014; 63(27):588-90.

33. Brener ND, Kann L, McManus T, et al. Reliability of the 1999 youth risk behavior survey questionnaire. J Adolesc Health 2002; 31(4):336-42. 


\section{Annex 1. \\ Survey template}

\section{SURVEY ON SMOKING AMONG YOUTH}

Sex: Male. $\square \quad$ Female. $\square \quad$ Age: __. School year:___. School:

1. In relation to cigarettes (choose one):
a) I have never smoked cigarettes.
b) I do not smoke but I have tried cigarettes.
c) I used to smoke but I have quit (choose one): More than 1 year ago./ Less than 1 year ago.
d) I smoke but not every day. $\square$
e) I smoke every day.

2. If you do not smoke (choose one):

I have considered starting smoking. $\square \quad$ I have considered smoking again. $\square \quad$ I do not want to try.

3. Do you live with smokers?

$\begin{array}{ll}\text { Father. } & \text { Sibling. } \\ \text { Mother. } & \\ & \text { Others.... } \\ & \text { (Who?): }\end{array}$

4. Do you have friends or family who quit smoking in the past year? Yes. $\square \quad$ No. $\square$

5. What do you do when you are with someone who smokes?

口I do not mind people smoking. $\quad$ I d do not like it but I do not say anything. $\quad$ I ladvise them to stop smoking.

6. Do you have friends who smoke? $\quad$ Yes. $\square \quad$ No. $\square$

7. Do you know the harmful effects of cigarettes on your heart? Yes. $\square \quad$ No. $\square$

\section{IF YOU SMOKE:}

8. At what age did you start smoking? At years old.

9. Why did you start smoking? (you may choose one or more options).

$\square$ Because my friends smoked.

$\square$ Because it made me feel safe.

$\square$ Because my family smoked.

$\square$ Because it made me look cool.

$\square$ Other (Why?):

10. Does your family know you smoke?

Yes.

No. $\square$

11. Do you see your physician as someone who could help you quit?

Yes.

No. $\square$ 


\section{Annex 2. Thematic units of the educational intervention}

1. Smoking in the world and in Argentina: Epidemiology of tobacco, impact on smoking-related mortality worldwide and in Argentina, tobacco-related expenses.

2. Harmful effects of tobacco on your body I: Main harmful effects of tobacco use on the heart, brain, and peripheral arteries.

3. Harmful effects of tobacco on your body II: Main harmful effects of tobacco use on the lungs, neoplasms, and aesthetics.

4. Smokers and others: Second-hand smoking, smoking and pregnancy, smoking and children.

5. Anti-smoking campaign: Anti-smoking poster proposed by the team. 